\title{
An Analysis Of The e-Business Program In The School Of Business Curriculum
}

Shyamalendu Sarkar, (E-mail: ssarkar@svsu.edu), Saginaw Valley State University Surender Reddy, (E-mail: reddy@svsu.edu), Saginaw Valley State University

\begin{abstract}
The article analyzes various present and future aspects of e-business as it is or should be incorporated in the school of business curriculum. The study uses both primary and secondary data. The results indicate that e-business courses are currently taught across the traditional disciplines of business schools. The courses are primarily taught as independent electives or as part of a regular course. The faculty preference for the future of e-business courses seems to be in the same direction, maybe even more extreme. Currently, a minority of schools do offer a certificate, major, or degree program in e-business.
\end{abstract}

The current levels of e-business courses, faculty expertise, and faculty development funds all seem to be less than satisfactory.

The sudden and significant decline in internet-based businesses did have significant negative effects on the number of course offerings in e-business and student enrollment in these courses. However, a significant number of respondents believe that the importance of e-business, hence e-business courses, will increase in the future.

\section{INTRODUCTION}

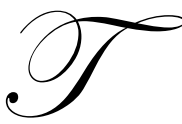

he World Wide Web has revolutionized the way that business is conducted, and business schools were faced with the challenge of incorporating e-business into the business school curriculum. In the year 2000, there were eighty-three e-business programs offered at AACSB affiliated schools which could be classified into one of the four categories: Master of Business Administration (MBA), Master of Science (MS), Bachelor of Science (BS), and non-degree certificate (Etheridge et al., 2001). With the bursting of the Internet bubble and recent market adjustments of e-business companies, it is time for business schools to refocus on the proper present and future status and role of e-business in their curriculum. The proposed study is intended to generate useful information in that direction; more specifically, the objectives of the present study are to determine: (1) the current state of the coverage of e-business topics in the School of Business curriculum; (2) appropriate topics and place of coverage of e-business courses in the future; (3) the impact of the decline of internet dependent businesses on offering of e-business courses and the levels of student interest; and (4) the factors important for a successful academic program in e-business.

The authors believe, although important, a rigorous study of these objectives would require substantially more data. This data are not expected to be available within a reasonable cost and time because e-business, as an area in the business curriculum, is at an early stage of development, and relatively few schools offer a well-rounded program compared to the traditional areas in business schools. However, the authors consider the study worth undertaking, since there are hardly any studies available addressing the above objectives. 


\section{THE DATA SOURCE}

As mentioned earlier, e-business courses are part of the curriculum of business schools at different levels with varying scope and intensity of the program. Clearly these schools have the experience with various aspects of designing and teaching e-business courses. To capture the experiences, the programs and the plans of these schools, the authors collected pertinent data through a questionnaire-based survey of most of these schools. Special attempts were made to contact the individuals directly involved in administering or teaching the e-business courses. The survey data is supplemented with information about e-business programs of business schools around the globe which are publicly available through the internet. The survey questionnaire was designed to focus on the objectives of the study. Further, the survey questionnaires were pre-tested for clarity of understanding and ease of response. There were a total of fourteen questions.

According to the above plan, the survey questionnaires were mailed to 70 faculty members and business schools identified as having programs or courses in e-business. To collect additional responses, a second mailing was also done. In the final calculation, only about 21 percent of the schools and individuals contacted had fully responded to the questionnaire. The respondents represented a variety of universities ranging from private (2), public (10), and international (3). The international universities were from United Kingdom, Belgium, and New Zealand. Although, a larger response was necessary for conducting specific statistical analysis, the sample size of 15 , from a small population together with additional publicly available information was considered adequate for statistical description of the data, and to draw relevant conclusion with respect to the objectives of the study stated above.

\section{RESULTS}

The responses to the fourteen questions in the survey are summarized below. The responses on some questions were combined together for a more meaningful interpretation.

\section{Sample Description}

The respondents reported having experience with teaching e-business classes and represented a variety of disciplines including MIS, Accounting, Management, Marketing, Economics, and e-commerce. Among the respondents with experience in teaching e-business classes, both undergraduate and graduate level courses were equally represented in the sample.

Table 1

\begin{tabular}{cc}
\hline Experience/Education & Number of Respondents \\
\hline Management/e-commerce & 3 \\
MIS/information science & 6 \\
Marketing & 3 \\
Economics & 2 \\
Accounting & 1 \\
\hline
\end{tabular}

\section{Programs/Courses Offered}

The respondents were asked to indicate the level of offerings in e-business at their respective schools. Some 
respondents indicated multiple levels of offerings.

Table 2

\begin{tabular}{cc}
\hline Level of Offerings & Number of Respondents \\
\hline Certificate in e-business & 5 \\
Degree in e-business & 2 \\
Concentration/major & 5 \\
Other & 8 \\
\hline
\end{tabular}

\section{Integration of e-Business in the Curriculum}

The respondents were asked to indicate the various ways by which e-business was being integrated into the curriculum. Some respondents have multiple responses, which results in the totals being greater than the number of respondents.

Table 3

\begin{tabular}{cc}
\hline Category & Number \\
\hline Required course in the core & 4 \\
Merged as topics/chapters into existing business/economics courses & 12 \\
Electives & 23 \\
Other & 2 \\
\hline
\end{tabular}

A reading of the responses indicates that most of the schools have infused e-business topics into their existing courses and offer discipline-specific electives in the area. A fewer number of schools have added an e-business class to their core. The results also indicate that most electives in e-business are offered by schools which have a concentration and/or certificate programs in e-business, which is to be expected since these schools have made most of the resource commitments.

It is interesting to note that when asked to rank their personal preference for integrating e-business courses into the curriculum, the respondents appear to prefer merging e-business topics into the existing curriculum or developing new courses. The interesting part of the responses is that there appears to be minimal support for a new degree program in e-business or a new major in the subject. This is perhaps a reflection of the market realities.

Respondent's preference for integrating e-business in the curriculum:

Table 4

\begin{tabular}{|c|c|c|c|c|c|}
\hline $\begin{array}{c}\text { Respondents } \\
\text { Ranking } \\
\end{array}$ & New Course & $\begin{array}{c}\text { New Major/ } \\
\text { Concentration }\end{array}$ & $\begin{array}{c}\text { Merged into } \\
\text { Existing Courses } \\
\end{array}$ & $\begin{array}{c}\text { New Degree } \\
\text { Program }\end{array}$ & Others \\
\hline 1 & 6 & 3 & 5 & 1 & - \\
\hline 2 & 5 & 1 & 5 & 1 & - \\
\hline 3 & - & 3 & 3 & - & 1 \\
\hline 4 & - & - & - & 4 & - \\
\hline 5 & 1 & - & - & - & - \\
\hline
\end{tabular}




\section{Extent of Coverage of e-Business}

The next group of questions dealt with the respondents' perception about the appropriate level of coverage and the level of expertise of faculty in their respective schools and college of business. The respondents were asked to indicate on a scale from 1 to $5(1=$ too much and $5=$ too little) about the intent of coverage of e-business topics in their discipline. Among the 15 respondents, 7 indicated that the extent of coverage was just right, while the remaining indicated that it was less than satisfactory. As more than 50 percent of the respondents indicated that the coverage was less than satisfactory without any counter-balancing responses, it can be reasonably concluded that the faculty believe that the coverage should be enhanced.

Table 5

\begin{tabular}{ccccc}
\hline Too Much & $\begin{array}{c}\text { More Than } \\
\text { Necessary }\end{array}$ & Just Right & $\begin{array}{c}\text { Less Than } \\
\text { Satisfactory }\end{array}$ & Too Little \\
\hline- & - & 7 & 8 & - \\
\hline
\end{tabular}

The respondents were then asked about the level of expertise in e-business among their faculty, and 8 out of the 14 responded that the level of expertise was less than satisfactory or poor.

\section{Level of Expertise}

Table 6

\begin{tabular}{ccccc}
\hline & & & Less Than & \\
Very High & Good & Moderate & Satisfactory & Poor \\
\hline 2 & 4 & - & 6 & 2 \\
\hline
\end{tabular}

To the question regarding availability of faculty development opportunities provided by their college to become more proficient in e-commerce, 9 of 15 respondents considered the support to be less than satisfactory. It is interesting to note that the respondents who felt that there was a lack of expertise among the faculty also felt they have not been provided with adequate development opportunities.

\section{Faculty Development Opportunities}

Table 7

\begin{tabular}{|c|c|c|c|c|c|}
\hline Level of Expertise & $\begin{array}{c}\text { Highly } \\
\text { Satisfied }\end{array}$ & Very Satisfied & Satisfied & Not Satisfied & Highly Dissatisfied \\
\hline Very high & \multirow{3}{*}{1} & & \multirow[t]{3}{*}{1} & 1 & \\
\hline Good & & 1 & & 2 & \\
\hline Moderate & & & & & \\
\hline Less than satisfactory & \multirow{3}{*}{1} & & 2 & 4 & \\
\hline Poor & & & & 1 & \\
\hline Not applicable & & & 1 & & \\
\hline
\end{tabular}

It seems that some faculty members developed satisfactory levels of expertise without having adequate development funds. In other cases, the funds were not properly used to develop expertise. 
The inconsistencies with respect to the availability of funds and the acquired level of expertise may be the result of the subjective nature of the evaluation on the part of the respondents. The preferred method of developing expertise was for the faculty to be provided funds to attend workshops and training seminars and to work with local businesses.

\section{Classroom Pedagogy}

The next question was regarding teaching an e-business class and if it required a different pedagogy. The overwhelming response was that it was not significantly different from any other course except for requiring a greater degree of technology enabled classrooms.

\section{Enrollment}

The next set of questions dealt with the collapse of the dot-com businesses and the effect on the number of courses offered and enrollment in e-business classes. To the question whether there was a decrease in the number of courses offered, 4 of the 10 respondents experienced reduction ranging from $25 \%$ to $60 \%$.

The follow-up question related to the change in the enrollment trends in e-business classes, and 7 of 10 respondents answered that the enrollment had decreased from $20 \%$ to $80 \%$. The final set of questions dealt with the respondents' perspectives regarding the future of e-business in the curriculum, 10 of 13 respondents felt that the emphasis on e-business in the curriculum would continue to increase, while the others believed that it would become just another topic in the traditional courses.

\section{Topics in e-Business}

The respondents were asked about the specific e-business topics that should be part of every business curriculum. Items reported in this open-ended question can be generalized into five areas: technical, marketing, supply chain, strategy, and economics.

\section{SUMMARY AND CONCLUSION}

As part of the school of business curriculum, the e-business courses are currently taught by almost every discipline. The courses are about equally distributed between the undergraduate and graduate levels. Most of the schools covered e-business topics in regular courses, others offered independent courses. Very few schools offered degrees in e-business. Further, the e-business courses are integrated into the curriculum primarily as electives or as a part of the existing business and economics courses. A small minority of schools required e-business in the core program. The majority of the faculty seemed to prefer that the e-business courses be incorporated in the existing courses or new courses be created to be offered as electives, taught across the curriculum. They also did not think that e-business courses required any special method except a greater use of technology.

More than fifty percent of the faculty felt that the coverage of e-business topics, as well as faculty expertise was less than satisfactory. The developmental opportunities including funds for faculty growth have been lacking.

The survey data further indicates that the dramatic decline in Internet based business in recent years has significantly negative effect on the number of course offering in e-business, as well as on student enrollment in these courses. Clearly the growth in the e-business area depends on faculty expertise, student interest, and market realities. Based on the survey responses, the authors believe that e-business, hence, the academic courses in e-business, will grow in importance in the future. 


\section{REFERENCES}

1. Etheridge, H., Hsu, K., \& Wilson, T. (2001). E-Business education at AACSB-affiliated business schools: A survey of programs and curricula. Journal of Education for Business, 76, 328-331.

\section{NOTES}

